\title{
HYDROLOGICAL PROCESSES OBTAINED ON THE PLOT SCALE UNDER FOUR SIMULATED RAINFALL TESTS DURING THE CYCLE OF DIFFERENT CROP SYSTEMS ${ }^{(1)}$
}

\author{
Ildegardis Bertol ${ }^{(2)}$, Roger Robert $\operatorname{Ramos}^{(3)}$ Fabrício Tondello Barbosa $^{(4)}$, Julio César \\ Ramos $^{(2)}$, Douglas Henrique Bandeira ${ }^{(2)} \&$ Mitsui Shinosaka Tanaka ${ }^{(5)}$
}

\begin{abstract}
SUMMARY
The cropping system influences the interception of water by plants, water storage in depressions on the soil surface, water infiltration into the soil and runoff. The aim of this study was to quantify some hydrological processes under no tillage cropping systems at the edge of a slope, in 2009 and 2010, in a Humic Dystrudept soil, with the following treatments: corn, soybeans, and common beans alone; and intercropped corn and common bean. Treatments consisted of four simulated rainfall tests at different times, with a planned intensity of $64 \mathrm{~mm} \mathrm{~h}^{-1}$ and 90 min duration. The first test was applied 18 days after sowing, and the others at 39, 75 and 120 days after the first test. Different times of the simulated rainfall and stages of the crop cycle affected soil water content prior to the rain, and the time runoff began and its peak flow and, thus, the surface hydrological processes. The depth of the runoff and the depth of the water intercepted by the crop + soil infiltration + soil surface storage were affected by the crop systems and the rainfall applied at different times. The corn crop was the most effective treatment for controlling runoff, with a water loss ratio of 0.38 , equivalent to $75 \%$ of the water loss ratio exhibited by common bean (0.51), the least effective treatment in relation to the others. Total water loss by runoff decreased linearly with an increase in the time that runoff began, regardless of the treatment; however, soil water content on the gravimetric basis increased linearly from the beginning to the end of the rainfall.
\end{abstract}

Index terms: runoff rate, runoff depth, soil water infiltration.

(1) Received for publication on April 19, 2013 and approved on December 11, 2013.

(2) Professor, Soil Department, Santa Catarina State University - UDESC/CAV. Av. Luiz de Camões, 2090. CEP 88520-000 Lages (SC), Brazil. CNPq Fellowship. E-mail: a2ib@cav.udesc.br

(3) Student, Graduate Studies Program in Soil Science, UDESC/CAV. E-mail: ramosrogerrobert@hotmail.com, julio.ramos.ta@gmail.com, douglas_ibf@hotmail.com

(4) Professor, Soil Department, UDESC/CAV. E-mail: a2ftb@cav.udesc.br

(5) Undergraduate research scholarship holder, UDESC/CAV. E-mail: mitsui_agro@hotmail.com 


\title{
RESUMO: PROCESSOS HIDROLÓGICOS OBTIDOS EM ESCALA DE PARCELA SOB QUATRO TESTES DE CHUVA SIMULADA, DURANTE O CICLO DE DIFERENTES SISTEMAS DE CULTIVO DO SOLO
}

\begin{abstract}
O sistema de cultivo influencia a interceptação de água pelas plantas, a armazenagem de água nas depressões do terreno, a infiltração de água no solo e o escoamento superficial. Este trabalho objetivou quantificar alguns processos hidrológicos em sistemas de cultivo do solo realizados em contorno no declive, em 2009 e 2010, em um Cambissolo Húmico alumínico, cuja área foi mantida sem preparo prévio do solo, nos seguintes tratamentos: solteiros - milho, soja e feijão; e consorciados - milho e feijão. Os tratamentos foram submetidos a quatro testes de chuva simulada, em épocas distintas, com intensidade planejada de $64 \mathrm{~mm} \mathrm{~h}^{-1}$ e duração de 90 min. O primeiro teste foi aplicado 18 dias após a semeadura e, os demais, aos 39, 75 e 120 dias, após o primeiro. Os diferentes momentos de aplicação das chuvas e os diferentes estádios do ciclo das culturas influenciaram o teor de água no solo antecedente às chuvas, o tempo de início e o de pico da enxurrada e, com isso, os processos hidrológicos de superfície. A lâmina de enxurrada e a de água interceptada pela vegetação + infiltrada no solo + armazenada superficialmente no solo sofreram a influência dos sistemas de cultivo e das chuvas aplicadas nas diferentes épocas. O cultivo de milho foi o tratamento mais eficaz no controle do escoamento superficial, com uma razão de perda de água de 0,38, equivalente a $75 \%$ da razão de perda de água apresentada pelo feijão $(0,51)$, que foi o tratamento menos eficaz em relação aos demais sistemas de cultivo. A perda total de água na forma de enxurrada decresceu linearmente com o aumento do tempo de início da enxurrada, independentemente do tratamento, enquanto o teor de água no solo em base gravimétrica aumentou linearmente do início ao final da chuva.
\end{abstract}

Termos de indexação: taxa de enxurrada, lâmina de enxurrada, infiltração de água no solo.

\section{INTRODUCTION}

Runoff is an important hydrological process used in planning for soil preservation, especially in determining the size of the hydraulic works concerned with water drainage and water storage from crops. Those processes are influenced by soil use and crop practices (Bertol et al., 2008) and by the soil water content reported prior to the rain (Gray \& Cogo, 1980), among other factors. Those factors affect water interception, surface storage and water infiltration into the soil, and are reflected in the beginning and the peak time of runoff, in the runoff rate and the total volume and water loss ratio (Schwab et al., 1993; Bertol et al., 2006).

Plants differ in relation to the morphological characteristics of roots and aerial parts, and thus affect soil properties and surface hydrological processes. The aerial part of plants dissipates rain energy and influences interception, water infiltration into the soil and runoff, even when there are no plant residues on the soil surface, due to conventional soil tillage (Wischmeier \& Smith, 1978), as verified by Gobbi et al. (2011) working in apple orchards. However, under no tillage, plant residues on the soil surface intercept and store water and, thus, increase water infiltration into the soil (Luciano et al., 2009).

The maturity stage of plants during their growing cycle affects soil surface hydrology as well, due to the variation of biomass from roots and aerial parts, which can influence soil water content, rainfall interception, water infiltration into soil and runoff. Engel et al. (2007; 2009), working with soybeans, Luciano et al.
(2009), working with oats and vetches, and Gobbi et al. (2011), studying apple orchards, evaluated water processes under several soil management systems using artificial rain. These authors observed important variations in some hydrological processes and hydraulic parameters throughout the crop cycle, reflecting water erosion. Amaral et al. (2008) observed the same variations working with natural rain on wheat and soybeans. In general, with the increase in the crop cycle, there was a decrease in soil water content, an increase in the beginning and the peak time of runoff, and a decrease in the volume of runoff and water erosion, in the case of simulated rainfall.

Different root systems of plants used in intercropping and crop rotation systems can act differently in soil aggregation, according to Cogo \& Streck (2003), Streck \& Cogo (2003) and Andrade et al. (2010). Legume and grass intercropping can improve some soil properties (Nolla et al., 2009), depending on crop development, influenced by the period of sowing (Dornelles et al., 1997). Corn (Zea mays) shows more effective roots in relation to soil structure, and its aerial part produces larger amounts of plant matter, intercepting rain drops, while common bean (Phaseolus vulgaris) and soybeans (Glycine max) have less effective roots to aggregate the soil and produce less aerial plant matter than corn (Calonego \& Rosolem, 2008). Those differences may be related to the rates of soil water infiltration and runoff, as verified by Luciano et al. (2009).

The aim of this study was to quantify rainfall, soil water infiltration + water interception by crops + soil surface storage, and runoff, under simulated rainfall 
conditions, in crop systems (corn, soybeans, and common bean alone; and intercropped corn and common bean), assessed on the border of the downward gradient, under no tillage.

\section{MATERIALS AND METHODS}

This study was performed in the field, from 2009 to 2010, on a Humic Dystrudept soil (Soil Survey Staff, 1999) developed from siltstones and argillites. The experimental area is situated at $27^{\circ} 46^{\prime} 57^{\prime}$ 'S latitude and $50^{\circ} 18^{\prime} 20^{\prime \prime} \mathrm{W}$ longitude, with an average altitude of $900 \mathrm{~m}$, and a $\mathrm{Cfb}$, subtropical humid climate (Köppen).

The experimental area was initially under native pasture and, in April 2006, the soil was tilled using one plowing and three harrowings. Details of previous crop and management practices are described in Bertol et al. (2013). On December 1, 2009, on the already systematized area, the treatments were set up under no-tillage conditions.

Experimental plots were $(3.5 \mathrm{~m}$ wide $\times 11 \mathrm{~m}$ long down the slope $-38.5 \mathrm{~m}^{2}$ ), defined on the side and at the top by galvanized sheets placed $0.1 \mathrm{~m}$ into the soil. In the lower portion of the plot, a runoff sampler was installed, connected to a tube to conduct the flow to a trench located $6 \mathrm{~m}$ below, where runoff samples were collected during the rain according to the procedure used by Bertol et al. (2008).

Before setting up the treatments, soil from the experimental plots was characterized through physical properties at three random points distributed over the area in the 0-0.1 m layer. Bulk density was $1.28 \mathrm{~kg} \mathrm{dm}^{-3} ;$ macroporosity, $0.12 \mathrm{~m}^{3} \mathrm{~m}^{-3} ;$ microporosity, $0.39 \mathrm{~m}^{3} \mathrm{~m}^{-3}$; and total porosity, $0.51 \mathrm{~m}^{3} \mathrm{~m}^{-3}$; without statistical variation among the collection points. These properties were determined from samples collected using soil sample rings $(5 \mathrm{~cm}$ height $\times 5 \mathrm{~cm}$ diameter) and analyses were performed according to Embrapa (1997). Sand, silt and clay contents were $0.21,0.42$ and $0.37 \mathrm{~g} \mathrm{~kg}^{-1}$, respectively, in the 0-0.1 m layer.

Four treatments were set up with two replications, for a total of eight plots distributed in two blocks, with the treatments distributed at random. Before sowing, a tractor-mounted spaced planter for direct sowing opened 22 furrows in the soil in each plot. After that, crops were sown (December 1, 2009) using a handoperated spaced planter for the following treatments: Test 1 - corn alone, spaced at $0.5 \mathrm{~m}$ between rows and $0.33 \mathrm{~m}$ between furrows (three plants per furrow); Test 2 - soybeans alone, spaced at $0.5 \mathrm{~m}$ between rows and 0.1 between furrows (three plants per furrow); Test 3 - beans alone, spaced at $0.5 \mathrm{~m}$ between rows and $0.1 \mathrm{~m}$ between furrows (three plants per furrow); Test 4 - intercropped corn and beans, with three rows of beans between two rows of corn, spaced at $0.5 \mathrm{~m}$ between rows for both crops; $0.33 \mathrm{~m}$ between furrows for corn (three plants per furrow), and $0.1 \mathrm{~m}$ for beans (three plants per furrow). Beans were harvested on February 26, 2010, seven days before the application of simulated rain test 3 , and corn and soybeans were harvested after rain test 4 was applied.

In each treatment, four simulated rain tests were applied, at different periods, using planned and continuous intensity $\left(64 \mathrm{~mm} \mathrm{~h}^{-1}\right)$ for $90 \mathrm{~min}$, using a rotating-boom rainfall simulator (Swanson, 1965). Test 1 was applied on December 18, 2009; test 2 on January 26, 2010; test 3 on March 3, 2010; and test 4 on May 14, 2010.

Natural rain that occurred during the interval of application of the simulated rainfall tests was measured. From sowing to Test 1, it rained five times $(49 \mathrm{~mm})$; from Test 1 to 2 there were 17 rains (199 $\mathrm{mm})$; from Test 2 to 3 , it rained 16 times $(190 \mathrm{~mm})$; and from Test 3 to 4 , there were 15 rains $(186 \mathrm{~mm}$ ).

Before the beginning of each simulated rainfall, during application and after the end, soil samples were collected in the center of each plot at a depth of 0-0.1 and 0.1-0.2 $\mathrm{m}$ in order to determine gravimetric soil content, according to Embrapa (1997). Samples were collected using a Dutch auger. The first collection was performed before the beginning of the rainfall; the second and third at 30 and 60 min after the rainfall began, respectively; and the fourth collection was made after the end of the rainfall.

During application of simulated rainfall, the start and peak time of runoff and the duration of the artificial rainfall applied were recorded, and all rainfall volumes were monitored through 22 rain gauges located under the simulator in order to calculate rainfall intensity and depth. Samples of surface runoff were collected every $5 \mathrm{~min}$, according to the method described in Bertol et al. (2008). Thus, the runoff rate and depth and the water loss ratio due to surface runoff were calculated to elaborate the hydrographs. Water loss ratio was calculated by the relationship between the runoff depth observed in each treatment and the applied artificial rainfall depth. The runoff depth adjusted to the simulated rainfall intensity was also estimated. That adjustment was required because of the intensity variation between the applied artificial rain (Table 1) and the planned artificial rain. The adjusted runoff depth was evaluated by dividing the planned rainfall intensity by the applied rainfall intensity and multiplying the result by the observed runoff depth. Water depth due to soil infiltration + interception by plants + soil surface storage was calculated by the difference between the applied simulated rainfall depth and the observed runoff depth.

The effects of treatments and rainfall tests on the parameters were tested using analysis of variance ( $4 \times 4$ factorial design). When parameter values were statistically different, their averages were compared by Tukey's test (5\% significance). 
Table 1. Soil water content, before the beginning of simulated rainfalls, and intensity and depth of the applied simulated rainfalls, 90 min duration, under four treatments and rainfall tests, in a Humic Dystrudept soil

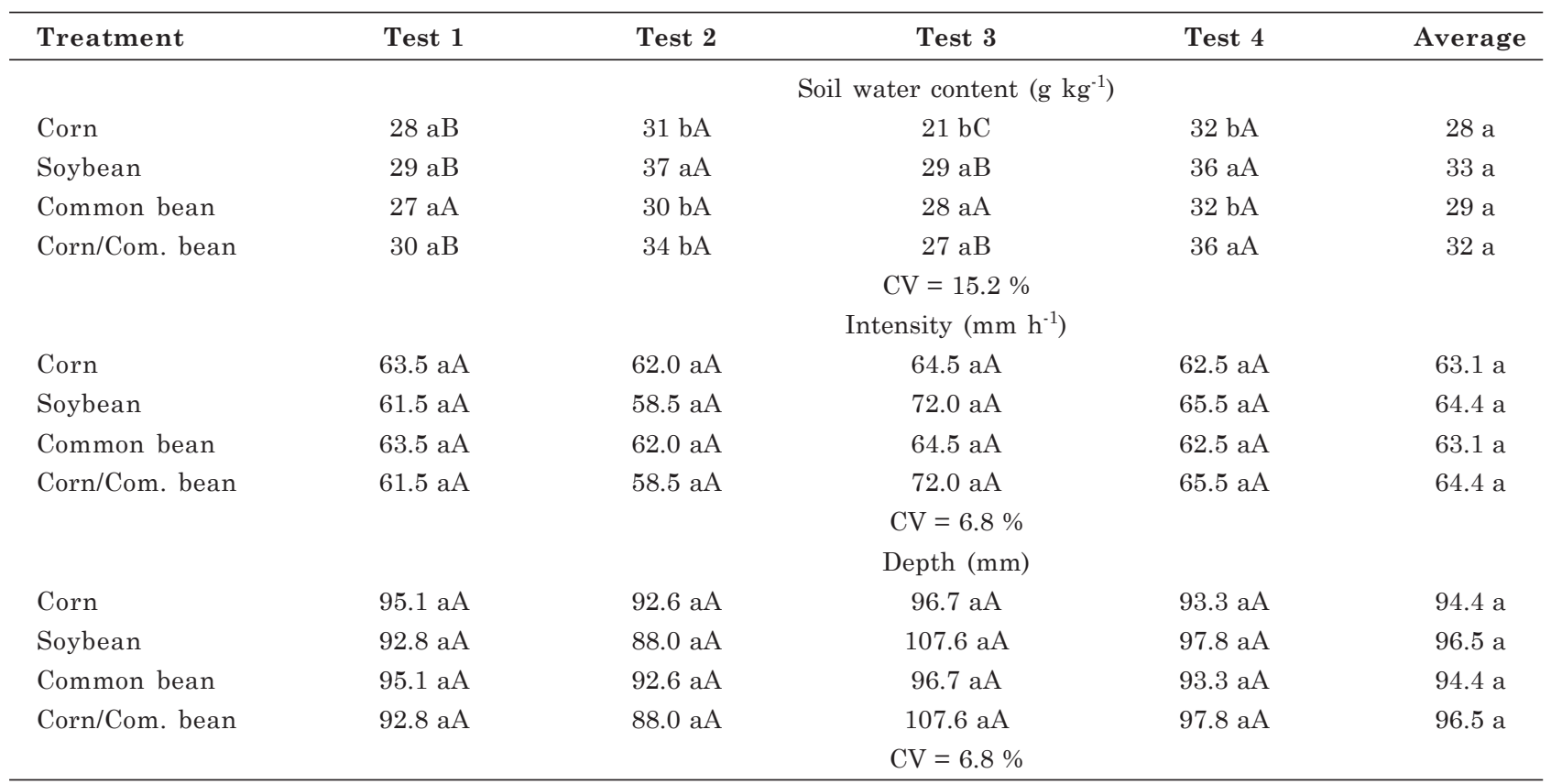

Lowercase letters compare treatments in each rainfall test and average of tests; uppercase letters compare rainfall tests in each treatment, by Tukey's test $(\mathrm{p}<0.05)$.

\section{RESULTS AND DISCUSSION}

Water content in the soil before simulated rainfall showed variance among treatments, except for Test 1 , and among the rainfall tests, except for the common bean treatment (Table 1). This is normal behavior, considering that rainfall tests were applied at different times, and treatments were composed of different crops. Thus, climate and crop growing variations over the time of the experiment, and water consumption by crops, influenced the time needed for the beginning of surface runoff from the applied rainfall tests. Similar data were observed in other studies (Gray \& Cogo, 1980; Luciano et al., 2009; Gobbi et al., 2011; Barbosa et al., 2012).

There was no statistical variation among simulated rainfalls in intensity and depth (Table 1); therefore, this variable had no effect on the hydrological parameters studied. Most of the rain intensities were quite close to the planned value $\left(64 \mathrm{~mm} \mathrm{~h}^{-1}\right)$, except for the rain of Test 3 , under the soybean and corn/ common bean treatments, whose value was $13 \%$ higher than the planned intensity. Variations between applied and planned simulated rainfall intensities are normal in such studies, as reported by Bertol et al. (2008), Luciano et al. (2009) and Gobbi et al. (2011).

The time runoff began, Rs, varied widely among rainfall tests in each treatment, without variation among treatments in each test (Table 2), and this was partly influenced by soil water content before rainfall application (Table 1). So, Rs values were higher in Tests 1 and 3 than in the others under tests under corn, common bean and corn/common bean treatments, and the Rs values were higher in Test 3 than in the other tests under the soybean. The Rs average values under corn, common bean and corn/ common bean treatments for Tests 1 and 3 were 2.4 times higher than these treatments in Tests 2 and 4 . This showed the temporal variation in soil water content and the crop development stage. For the soybean treatment, the variation between the higher Rs value in Test 3 and the average of the two lower values in Tests 2 and 4 was 3.1 times. Rs value is an important variable for determining soil water infiltration and surface runoff, as verified by Bertol et al. (2008) and Luciano et al. (2009).

The times for peak runoff values, Rp, showed the same trend as Rs in accordance with the effect of rainfall tests in each treatment (Table 2), indicating that Rs influenced Rp. So, we were able to see that these two variables were influenced by soil water content before the rainfalls and by crop growing over the time of the experiment, as shown by Luciano et al. (2009) and Gobbi et al. (2011).

The sum of soil water infiltration + water interception by crops + soil surface storage, Sws, was higher in rainfall Tests 1 and 3 than in tests 2 and 4 (Table 3). Especially in rainfall Tests 1 and 3, the Sws values can be considered higher in relation to the rainfall depths applied (Table 1). These results 
may be related to the combined effects of soil water content before the rainfalls (Table 1) and the Rs and Rp times (Table 2), as verified by Bertol et al. (2008), Luciano et al. (2009) and Gobbi et al. (2011). The results may also be due to the characteristics of the applied rainfalls (Table 1), as reported by Panachuki et al. (2011). In the average of the treatments, the Sws values were $90 \%$ higher in rainfall Tests 1 and 3 than in Tests 2 and 4, showing the dependence of these conditions, especially in regard to soil water content before application of simulated rainfall. Crop treatments had a significant effect on Sws in rainfall Tests 3 and 4 (Table 3). The common bean alone treatment showed Sws inferior to corn and soybeans in Test 3 and inferior to corn in Test 4. This result can be explained because the common bean harvest occurred before rainfall Test 3 , which is related to shorter duration of the common bean cycle in comparison to the other crops, causing a bare soil surface condition with no cover protection after

Table 2. The time runoff began and time of peak runoff, under four treatments and rainfall tests, on a Humic Dystrudept soil

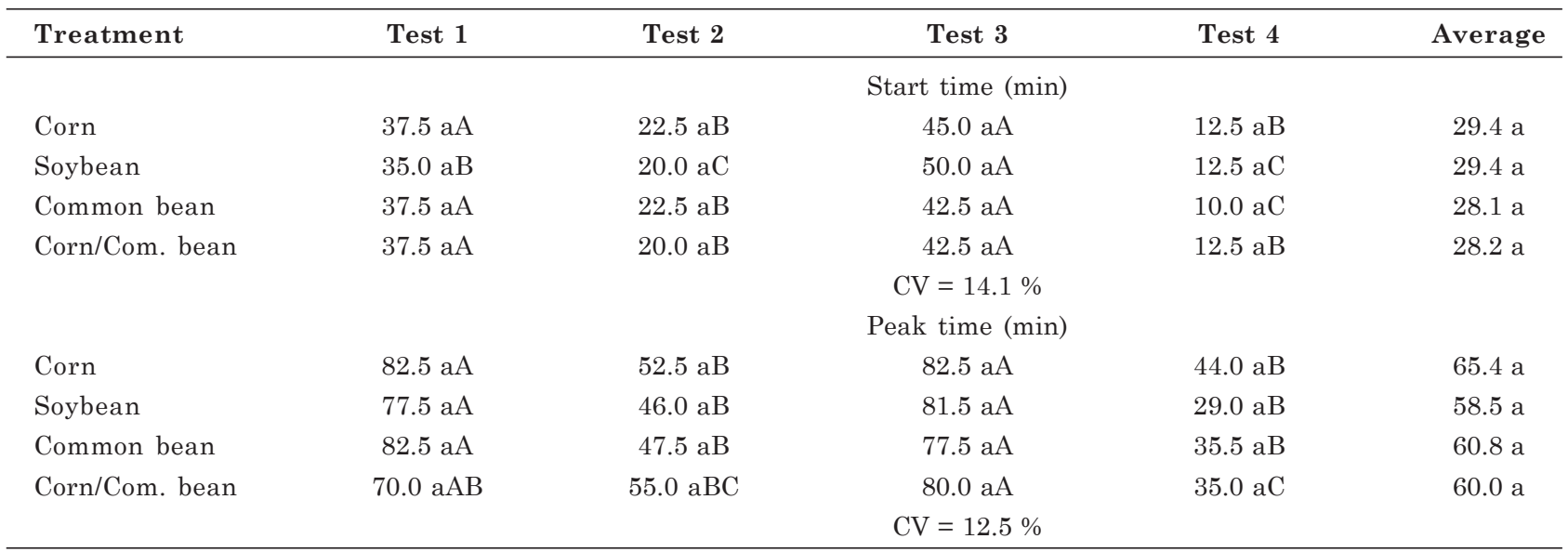

Lowercase letters compare treatments in each rainfall test and in the average of the tests; uppercase letters compare rainfall tests in each treatment, by Tukey's test $(p<0.05)$.

Table 3. Sum of the soil water infiltration + interception by crop + soil surface depths, and runoff depth adjusted for rainfall intensity of $64 \mathrm{~mm} \mathrm{~h}^{-1}$ and water loss ratio by runoff, under four treatments and rainfall tests, on a Humic Dystrudept soil

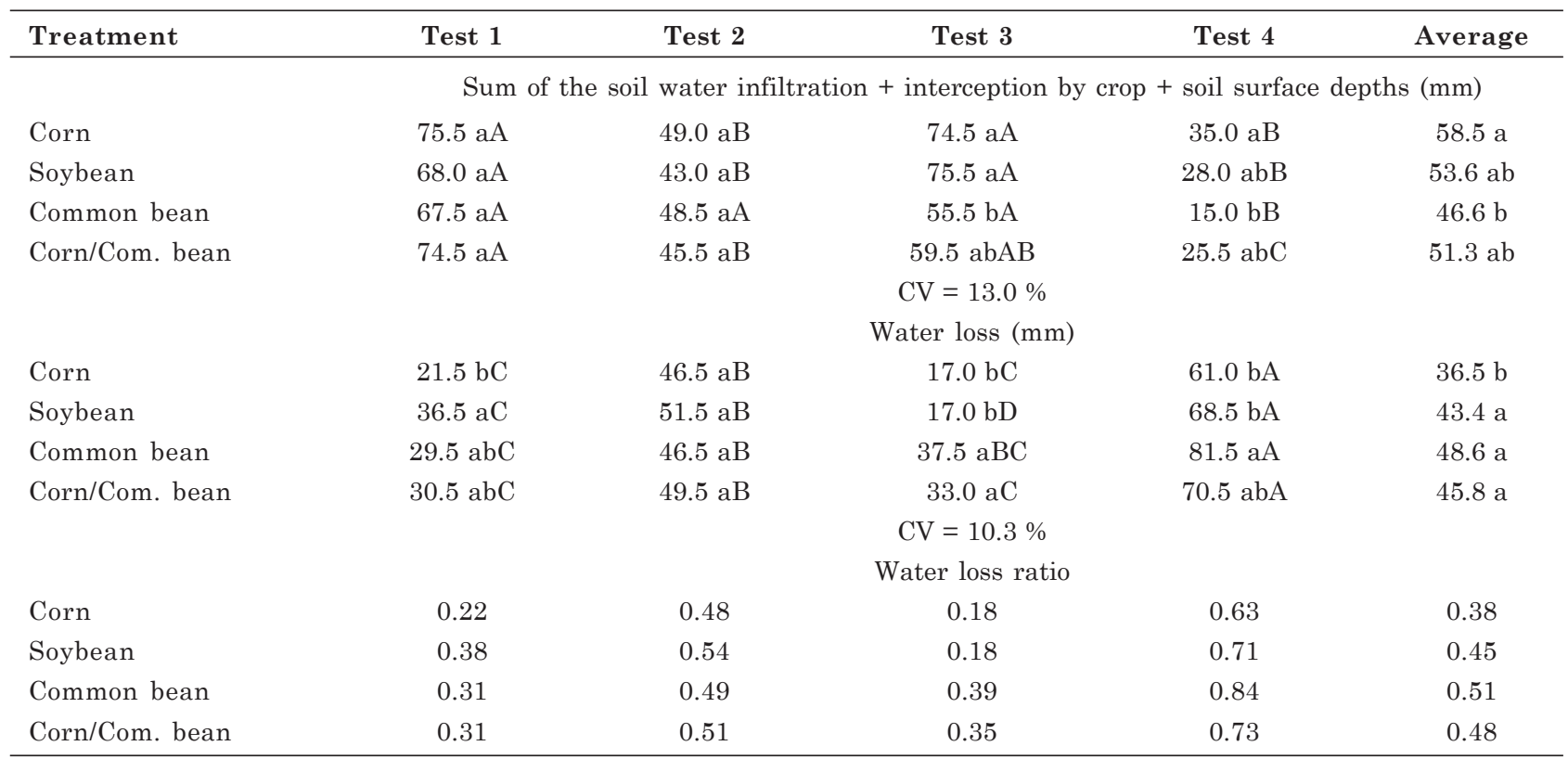

Lowercase letters compare treatments in each rainfall test and average of tests; uppercase letters compare rainfall tests in each treatment, by Tukey's test $(\mathrm{p}<0.05)$. 
Test 3. The corn/common bean treatment was not statistically different from the others, thus indicating the effectiveness of the intercropping treatment for soil water infiltration.

In the average of the rainfall tests (Table 3) and in the sum of the four rainfall tests (Figure 1a), corn differs from the other crops, and it is more effective in increasing infiltration, interception and soil surface storage, exhibiting higher values for these variables in rainfall Tests 1, 2 and 4; it is thus an important crop for soil and water conservation. The Sws constitutes up to $62 \%$ of the simulated rainfall depth treatment for corn, and for soybeans, common bean and corn/common bean treatments, it reaches 56, 49 and $53 \%$, respectively (Figure $1 \mathrm{~b}$ ). This emphasizes the conservationist status of corn, with higher soil water infiltration in relation to the other crops, and also indicates that common bean was the least effective crop in relation to soil water infiltration.

Variation in water loss values was affected by the combined hydrological variables related to runoff, as also verified by Panachucki et al. (2011) and Barbosa et al. (2012). The effectiveness of the corn crop in reducing water losses in rainfall tests 1,3 and 4 may be seen, followed by soybeans, which were effective in rainfall Tests 3 and 4 (Table 3). In the sum of the four tests, corn significantly reduced water loss through runoff by $21 \%$, in relation to the average of the other treatments (Figure 1). This is in agreement with result obtained by Leite et al. (2004) comparing corn and common bean crops in a Haplic Nitosol. The water loss ratio (Wlr) clearly shows the effectiveness of the crop in controlling runoff. These values were relatively low in Tests 1 and 3, ranging from 0.22 to 0.38 in
Test 1 and 0.18 to 0.39 in Test 2 . However, values were higher for Tests 2 and 4, from 0.48 to 0.54 , and 0.63 to 0.84 , respectively.

The high quantity of water lost by runoff in some treatments, especially in Test 4 and at the end of the crop cycle (Table 3), suggests the need for mechanical structures for runoff control under critical rainfall conditions, as argued by Barbosa et al. (2012). Although there was no statistical difference among some treatments, these values of water loss can be useful for dimensioning hydraulic structures for control of water on the soil surface. Thus, for appropriate dimensioning of terraces, for example, the average water loss for soybeans $(43.4 \mathrm{~mm}$, Wlr $=0.45)$ can be considered different from the average water loss for common bean $(48.6 \mathrm{~mm}$, Wlr $=0.51)$, even though these values are statistically similar (Table 3 ). So, the kind of crop clearly influenced Wlr, as confirmed by other authors (Schick et al., 2000; Leite et al., 2004; Bertol et al., 2006, 2008).

Water loss values as reflected in runoff depth decreased in a linear manner with an increase in the values of the time runoff began, $R s$, in a statistically significant manner (Figure 2). The increase in Rs values was positively related to the time of peak runoff, $\mathrm{Rp}$ (Table 1). This is expected because a higher Rs means the greater the time available for crop interception by foliage; it is likewise related to a high soil surface storage and high soil infiltration. In contrast, the higher the Rp, the longer the time needed for water to flow on the soil surface as runoff. Similar results were obtained by Bertol et al. (2008).

The values of runoff rate were different among the simulated rainfall tests and, in Tests 1 and 3 , there

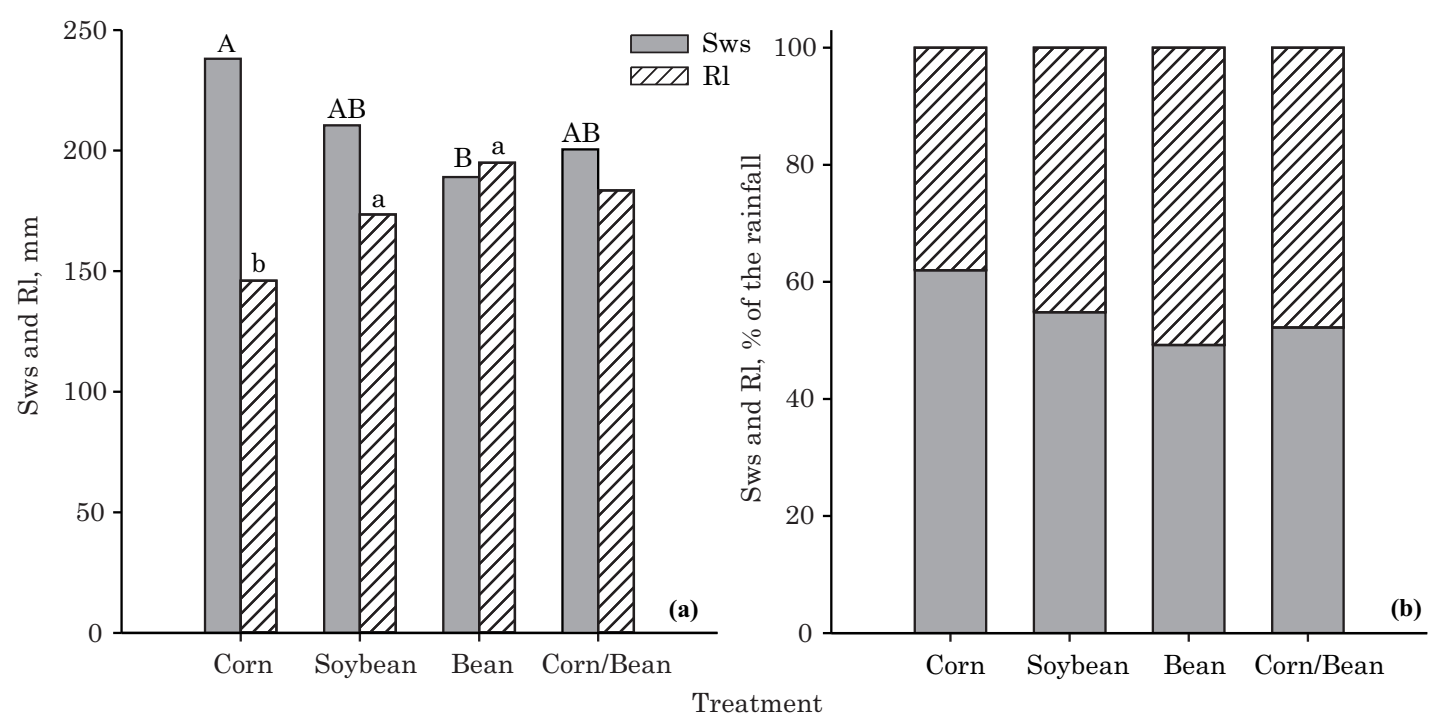

Figure 1. Soil water infiltration + interception by crops + soil surface storage depths, Sws, and runoff depth, $\mathrm{Rl}$, adjusted for rainfall intensity of $64 \mathrm{~mm} \mathrm{~h}^{-1}$, in the sum of four rainfall tests, under four treatments, on a Humic Dystrudept soil: (a) Sws and Rl in mm; (b) Sws and Rl in \% of the applied rainfall depth. Uppercase letters compare Sws $(\mathrm{CV}=13.4 \%)$ and lowercase letters compare Rl (CV = 10.3 \%), by Tukey's test $(\mathbf{p}<0.05)$. 
were differences among the treatments (Figure 3). Thus, in the two cases in which soil water content before rainfalls was low, as in rainfall Tests 1 and 3 , differences among treatments were more striking and the peak runoff time was delayed but became numerically distinct. When soil water content was high, as in rainfall Tests 2 and 4, differences among the treatments were minimized and the peak runoff time was earlier. It may be assumed that hydraulic structures to control surface runoff should be designed taking into account results obtained from runoff events, first from heavy rains and, secondly, considering high soil moisture, in order to maximize the runoff. High runoff depths can occur under extreme rainfall conditions, regardless of the cropping system in agricultural areas, as reported by Barbosa et al. (2012).

Soil water content was positively and linearly related to the increase in the duration of the simulated rainfalls applied, considering samples collected immediately before the beginning of the rainfalls (Figure 4). The response in that variable is expected since water, when infiltrating into soil, occupies pores and increases soil moisture content. Conversely, when rainfall stops, water quickly drains from the largest pores, reducing water content. The importance of these results is related to knowing how soil water contents increase and decrease during the application of high intensity rainfall, for which there is no published data in Brazilian literature for Humic Dystrudept soil.

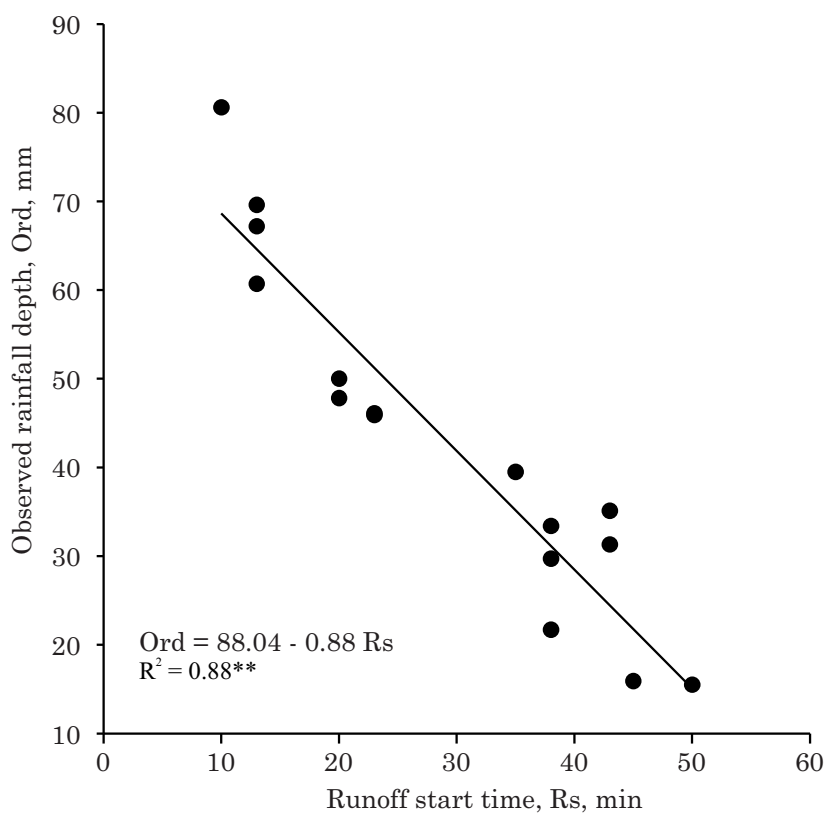

Figure 2. Relation between the observed runoff depth, Ord, and the runoff start time, Rs, under four treatments and rainfall tests, on a Humic Dystrudept soil.

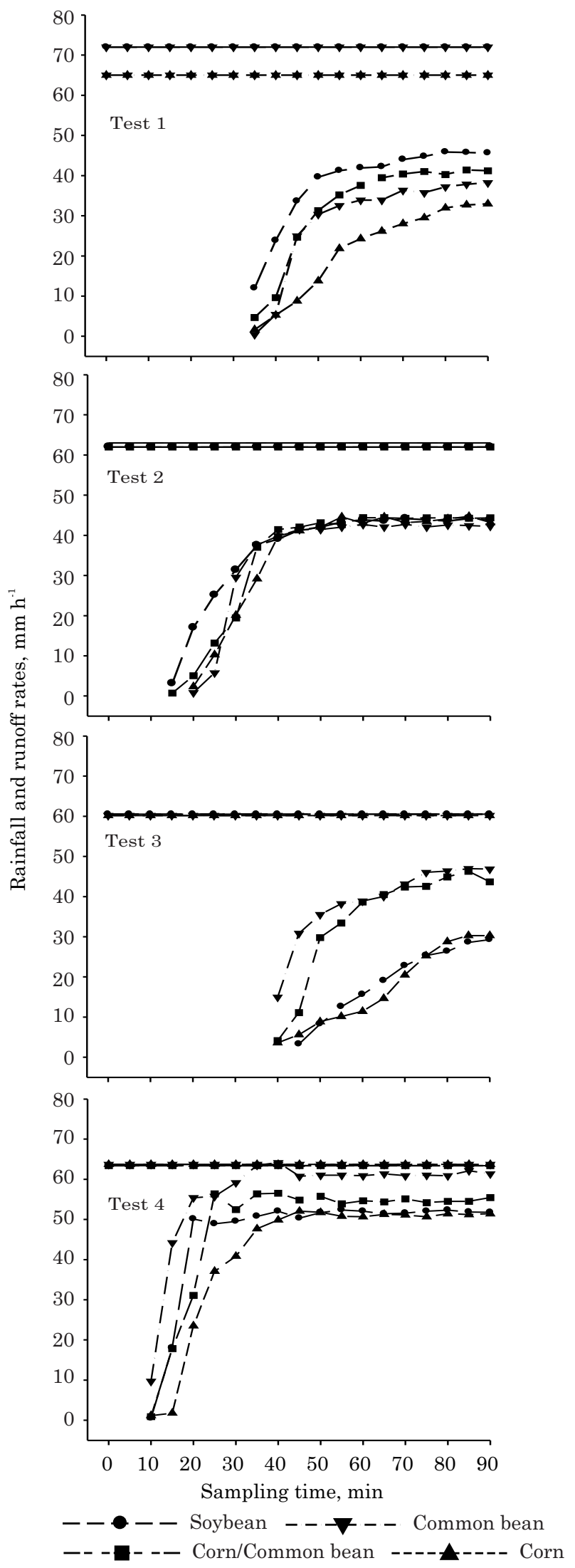

Figure 3. Rainfall and runoff rates over the sampling time, under four treatments and rainfall tests, on a Humic Dystrudept soil. 

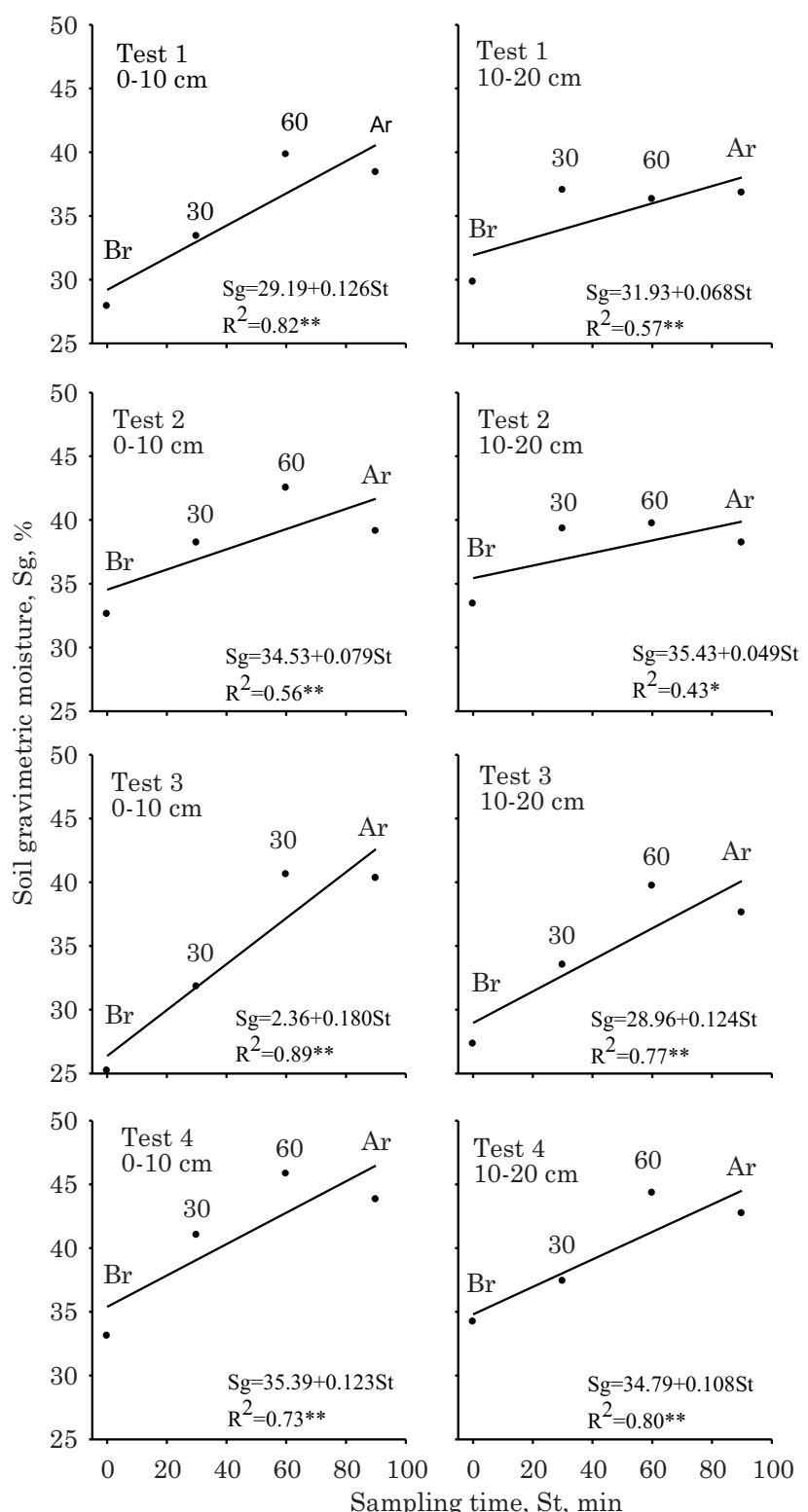

Figure 4. Relation between soil gravimetric moisture, Sg, and sampling time, $\mathrm{St}$, in two soil layers, for four rainfall tests, on a Humic Dystrudept soil (average of treatments and replicates). Br: before the rainfall; 30 and 60: 30 min and $60 \mathrm{~min}$ after the rainfall began, respectively; Ar: after the rainfall ended.

\section{CONCLUSIONS}

1. Different times for rainfall application at different stages of crop cycles influenced soil water content before rainfalls, as well as the time runoff began and the time of peak runoff.

2. The runoff depth and the sum of interception by crops + infiltration + soil surface storage depths were influenced by crop systems, the stage of crop development and the rainfall applied at different times.
3. The corn crop was the most effective factor in controlling runoff, with a water loss ratio of 0.38 , equivalent to $75 \%$ of the water loss ratio shown by common bean (0.51), the least effective treatment in relation to the others (soybeans, corn and corn + beans), in the sum of the simulated rainfall tests.

4. Total water loss by runoff decreased linearly with the increase in the time runoff began, regardless of the treatment; however, soil water gravimetric content increased linearly from the start to the end of rainfall.

\section{LITERATURE CITED}

AMARAL, A.J.; BERTOL, I.; COGO, N.P. \& BARBOSA, F.T. Redução da erosão hídrica em três sistemas de manejo do solo em um Cambissolo Húmico da região do Planalto Sul-Catarinense. R. Bras. Ci. Solo, 32:2145-2155, 2008.

ANDRADE, A.P.; MAFRA, A.L; BALDO, G.R.; PÍCOLLA, C.D.; BERTOL, I. \& ALBUQUERQUE, J.A. Physical properties of a Humic Cambisol under tillage and cropping systems after 12 years. R. Bras. Ci. Solo, 34:219-226, 2010.

BARBOSA, F.T.; BERTOL, I.; WERNER, R.S.; RAMOS, J.C. \& RAMOS, R.R. Comprimento crítico de declive relacionado a erosão hídrica, em três tipos e doses de resíduos em duas direções de semeadura direta. R. Bras. Ci. Solo, $36: 1279-1290,2012$.

BERTOL, I.; BARBOSA, F.T.; FABIAN, E.L.; PEGORARO, R.; ZAVASCHI, E.; PAZ GONZÁLEZ, A. \& VIDAL VÁZQUEZ, E. Escoamento superficial em diferentes sistemas de manejo em um Nitossolo Háplico típico. R. Bras. Eng. Agric. Amb., 12:243-250, 2008.

BERTOL, I.; MELLO, E.L.; COGO, N.P.; VIDAL VÁZQUEZ, E. \& PAZ GONZÁLEZ, A. Parâmetros relacionados com a erosão hídrica sob taxa constante de enxurrada, em diferentes métodos de preparo do solo. R. Bras. Ci. Solo, 30:715-722, 2006 .

BERTOL, I.; RAMOS, R.R.; BARBOSA, F.T.; PAZ GONZÁLEZ, A.; RAMOS, J.C. \& BANDEIRA, D.H. Water erosion in no-tillage monoculture and intercropped systems along contour lines. R. Bras. Ci. Solo, 37:521-528, 2013.

COGO, N.P. \& STRECK, E.V. Surface and subsurface decomposition of a desiccated grass pasture biomass related to erosion and its prediction with RUSLE. R. Bras. Ci. Solo, 27:153-164, 2003

CAlonego, J.C. \& ROSolen, C.A. Estabilidade de agregados do solo após manejo com rotações de culturas e escarificação. R. Bras. Ci. Solo, 32:1399-1407, 2008.

DORNELLES, E.L.B.; MENDEZ, M.G.; CORRÊA, L.A.V. \& SCHUCH, L.O.B. Arranjos de plantas e épocas de semeadura no cultivo consorciado de feijão (Phaseolus vulgaris L.) e milho (Zea mays L.) na região sul do Rio Grande do Sul. R. Bras. Agroci., 3:11-16, 1997. 
EMPRESA BRASILEIRA DE PESQUISA AGROPECUÁRIA EMBRAPA. Serviço Nacional de Levantamento e Classificação dos Solos. Manual de métodos de análise do solo. Rio de Janeiro, 1997. 212p.

ENGEL, F.L.; BERTOL, I.; MAFRA, A.L. \& COGO, N.P. Water erosion under simulated rainfall in different soil management systems during soybean growth. Sci. Agric., 64:187-193, 2007.

ENGEL, F.L.; BERTOL, I.; RITTER, S.R.; PAZ GONZÁLEZ, A.; PAZ-FERREIRO, J. \& VIDAL VÁZQUEZ, E. Soil erosion under simulated rainfall in relation to phenological stages of soybeans and tillage methods in Lages, SC, Brazil. Soil Till. Res., 103:216-221, 2009.

GOBBI, E.; BERTOL, I.; WERNER, R.S.; RAMOS, R.R.; PAZFERREIRO, J. \& GEBLER, L. Erosão hídrica associada a algumas variáveis hidrológicas em pomar de maçã submetido a diferentes manejos do solo. R. Bras. Ci. Solo, 35:1013-1024, 2011.

GRAY, D.D. \& COGO, N.P. Antecedent moisture condition probabilities in Tippecanoe County, Indiana. In: WARNER, R.E. \& CLARK, P.E., eds. Water Resources and Land Use Management in Indiana. Indianapolis, Indiana Water Resources Association, 1980. p.157-176.

LEITE, D.; BERTOL, I.; GUADAGNIN, J.C.; SANTOS, E.J. \& RITTER, S.R. Erosão hídrica em um Nitossolo Háplico submetido a diferentes sistemas de manejo sob chuva simulada. I - Perdas de solo e água. R. Bras. Ci. Solo, 28:1033-1044, 2004.

LUCIANO, R.V.; BERTOL, I.; BARBOSA, F.T.; VÁZQUEZ, E.V. \& FABIAN, E.L. Perdas de água e solo por erosão hídrica em duas direções de semeadura de aveia e ervilhaca. R. Bras. Ci. Solo, 33:669-676, 2009.
NOLLA, A.; JUCKSCH, I. \& ALVARENGA, R.C. Cobertura do solo proporcionada pelo cultivo consorciado de milho com leguminosas e espécies espontâneas. Cultivando o Saber, 2:151-163, 2009.

PANACHUKI, E.; BERTOL, I.; ALVES SOBRINHO, T.; OLIVEIRA, P.T.S. \& RIDRIGUES, D.B.B. Perdas de solo e de água e infiltração de água em Latossolo Vermelho sob sistemas de manejo. R. Bras. Ci. Solo, 35:1777-1785, 2011.

SCHICK, J.; BERTOL, I.; BATISTELA, O. \& BALBINOT JUNIOR, A.A. Erosão hídrica em Cambissolo Húmico submetido a diferentes sistemas de preparo e cultivo do solo: I. Perdas de solo e água. R. Bras. Ci. Solo, 24:427436, 2000.

SCHWAB, G.O.; FANGMEIER, D.D.; ELLIOT, W.J. \& FREVERT, R.K. Soil and water conservation engineering. 4.ed. New York, John Wiley \& Sons, 1993. $507 \mathrm{p}$.

SOIL SURVEY STAFF. Soil taxonomy. A basic system of soil classification for making and interpreting soil surveys. 2.ed. Washington, USDA-SCS, 1999. (Handbook, 436)

STRECK, E.V. \& COGO, N.P. Reconsolidation of the soil surface after tillage discontinuity, with and without cultivation, related to erosion and its prediction with RUSLE. R. Bras. Ci. Solo, 27:141-151, 2003.

SWANSON, N.P. A rotating-boom rainfall simulator. Trans. Am. Soc. Agric. Eng., 8:71-72, 1965.

WISCHMEIER, W.H. \& SMITH, D.D. Predicting rainfall erosion losses: A guide to conservation planning. Washington, USDA, 1978. 58p. (Agricultural Handbook, 537) 